\title{
The Croatians in Sydney
}

\section{Luka Budak and Walter F Lalich}

Croatian settlement in Sydney has a dynamic history of arrivals, desertions, internment, collective departures, and a continuously rich social and political life although only several hundred Croatians lived in Sydney until 1949. At least 5,000 Croatians lived in Australia in 1947, ${ }^{1}$ mostly from the coastal region of Dalmatia, mainly from the Makarska area and the island of Korcula. They made up around 80 per cent of all migrants from what was then Yugoslavia and a majority among the approximately 425 'Yugoslavs' who in lived in Sydney in that period. ${ }^{2}$ Many more arrived afterwards and at least 118,046 people in Australia, 33,930 in Sydney, were of Croatian ancestry in 2006. ${ }^{3}$ The experience of Croatians in Sydney is observed through two historical periods, linked by continuous market gardening in the northern suburbs of Mona Vale and Warriewood, and the western suburbs of Cabramatta and Blacktown. Inevitably, it must be understood against the background of the dramatic political and social events that Croatia and Croatians experienced over the twentieth century.

\section{Early Croatians}

It is likely that the first Croatian recorded in Sydney was convict John Blacovitch who arrived on the General Hewitt in 1814. More settlers of Croatian origin arrived later in the nineteenth century, including Luka Voinich from Dubrovnik who arrived in 1864 at the age of 23, and Teodor Serovic who had a vegetable farm in St Johns Park after he returned from the outback. It was mostly a male migration and some married locally, like John Jurich with Elisabeth Williamson in 1876; they had a daughter Emma in $1881 .^{4}$

During World War I, not many Croatians migrants volunteered to fight against Austria-Hungary, whose citizens they were. ${ }^{5}$ Unwillingly, many became temporary residents of Sydney as approximately 740 Croatian labourers, woodcutters, miners, gumdiggers and sailors from all over Australasia were interned in Holdsworthy-Liverpool concentration camp. ${ }^{6}$ Eventually, around 40 internees joined the Yugoslav Volunteer Legion; 27 died, one was shot dead. After the war when Yugoslavia was established out of the ruins of Austria-Hungary, about 574 internees were deported, mostly on the SS Frankfurt on 18 September 1919, while 100 were allowed to stay.

During the 1930s, Sydney, with better employment, working and living conditions, and access to better food, replaced the mining town of Broken Hill as a hub of Croatian settlement in New South Wales. ${ }^{7}$ Being mostly of peasant background, Croatian migrants found that work on farms suited them better than jobs in mines and sugar cane fields. They were among the pioneers in glasshouse tomato production, and had around 1,500 glasshouses in Warriewood by $1936 .{ }^{8}$ 
During World War II, over 240 Croatians, being foreign Yugoslav citizens, had to register as aliens in Sydney, and some with Italian citizenship were interned. Despite difficulties, some joined the Australian Imperial Force, while the majority were engaged in the militia and on the home front. ${ }^{9}$ Private Leslie T Starcevich (Borneo, 1945), born in Western Australia, is commemorated on the plaque in the Queen Victoria Building as one of 20 Australian Victoria Cross holders from World War II.

\section{Croatians in the Yugoslav Immigrants Association}

The key organisation of these hard-working and self-reliant, but ill-educated, unskilled labourers dispersed throughout Australia, was the left-oriented Yugoslav Immigrants Association of Australia (from 1933), established initially as a Militant Workers' Movement in 1928. Besides passing Australian immigration criteria, migrants had to pass a character test back home before securing travel loans through private channels. The association had its headquarters at 641 George Street, Sydney, with 30 branches Australia-wide. There were 1,007 voting members at the 1946 conference, 90 per cent of them Croatians ${ }^{10}$ though the association was open to all migrants from Yugoslavia. Their contingent at the May Day parades in Sydney during and immediately after World War II was led by a small Jadran tambouritsa band, whose instruments were purchased in 1938 through donations from Zagreb, and by the image of then little-known Marshal Tito, later President of Yugoslavia. ${ }^{11}$ Postwar Yugoslavia opened a consulate in Sydney in 1945; the first Consul, Ivan Kosovich, and other staff were recruited locally. ${ }^{12}$

The favourite picnic spots of this small community were on the Georges River at Casula, Hollywood Park near Cabramatta and Clifton Gardens on the North Shore. ${ }^{13}$ They established several clubs in rented and private properties.

\section{Building a community}

The first social and sporting club HSNK Zora (Dawn) was established in 1931 in rented premises in Campbell Street in the city. It was followed by Danica (Morning Star) in Cabramatta which had a bocce section. The tambouritsa band Jadran joined with it in 1938. Both lingered on until the early 1960s. ${ }^{14}$ The Yugoslav Immigrants Association had branches all around Sydney, including the social club Partisan established in 1944, which still exists under the name Leppington Bowling Club, with its own premises, while members of the Club Uzor in Blacktown met at private homes. Club Orjen was established in Warriewood before the war, and purchased its own property in $1949 .{ }^{15}$ A pro-royalist Yugoslav club was established in 1929. Its first president was businessman Josip Mikulicic-Rodd, later Honorary Royal Yugoslav consul. ${ }^{16}$ It had its own tambouritsa orchestra and cooperated briefly with other organisations across the ideological divide during World War II. 
Youth members of Zora, together with newly arrived settlers from Broken Hill, established a football club, Lola, in 1945 starting a long tradition of Croatian football clubs in Sydney. It also established a youth tambouritsa orchestra in 1947. The football club toured Broken Hill in 1947. ${ }^{17}$ In the same year, the oldest Croatian football club, Hajduk from Split, was the first European club to tour Australia after 1945; it played four games in Sydney and beat the national team 3-2 on 30 July 1949 in front of 27,000 spectators. ${ }^{18}$

The only Croatian language periodical in Australia, Napredak (Progress), was established in Sydney in 1936, after earlier publishing as Borba (Struggle) in Broken Hill from 1931. The first editor was Ivan Kosovich. It became the official voice of the Yugoslav Immigrants Association and supported the labour movement (in Yugoslavia and Sydney), the Communist Party, the Allies and a socialist Yugoslavia. Like other migrant political press, it was banned from mid-1940 until October 1942. The association raised funds in support of Allied war efforts and generated a collection of well over $£ 166,000$ in monetary and material support for Yugoslavia, mostly after the war. ${ }^{19}$

However, Napredak's promotion of the idea that Yugoslav immigrants should return home created grounds for its own decline. A sharp internal factional rupture followed the Tito and Stalin split in 1948; changed political circumstances and migrant demography led to the demise of Napredak in 1958 and of the association itself in $1960 .{ }^{20}$

\section{Going home 1948-49}

The most dramatic event in the lives of this generation of Croatian migrants was a collective return home during 1948 and 1949 on the ships Partizanka and Radnik, purchased for that purpose by the Yugoslav government. It was an exodus without parallel in Australian migration history, when over 1,100 people departed on ships that had brought other European migrants to Australia. The first 193 passengers embarked on the Partizanka in Sydney on 20 January 1948. ${ }^{21}$ They were fuelled by nostalgia and desire for family reunion after decades of separation, a sense of social and cultural belonging, desire to assist in the reconstruction of their war-ravaged country, political and emotional pressures, and socialist idealism; but also by their experience of hardships and prejudice in Sydney. ${ }^{22}$ 'Sydney was emptied of our people' commented Marin Grubisich, who remained. ${ }^{23}$ But, soon, many re-emigrated, disillusioned, and started anew in Australia together with refugees from communist Yugoslavia, and political and economic migrants who arrived with different experiences and agendas, creating a new Croatian settlement in Sydney.

\section{Croatians in Sydney after World War II}

The first Croatian migrants to arrive in Sydney in the years after World War II were mainly 'displaced persons' and refugees, survivors of the postwar atrocities, both soldiers and civilians. 
In the mid- and late 1950s they were joined by those who had experienced both the horrors of war and the difficult social, political and economic conditions of the first decade of the Yugoslav communist regime. Many fled Yugoslavia illegally, ${ }^{24}$ but were welcomed to Australia by the conservative Menzies federal government. ${ }^{25}$

The next 'wave' of Croatian migration to Australia, from Croatia, and from Bosnia and Herzegovina, was after Yugoslav communist authorities opened borders when faced with high rates of unemployment in the early $1960 \mathrm{~s} .{ }^{26}$ It was followed by migrants who arrived under Australia's unskilled and semi-skilled immigration scheme which lasted until the mid-1970s. ${ }^{27}$ The official attitude to Croatian migrants had by now changed, culminating, during the Whitlam Labor federal government, with raids on the homes of Croatians who were alleged to have participated in terrorist activities in Australia. ${ }^{28}$

In the 1980s, due to high rates of unemployment and political uncertainties, a number of skilled and professional people left Croatia for Sydney in a search of a better life. ${ }^{29}$ They were followed in the 1990s, by which time Yugoslavia was already defunct, by some refugees from Croatia and a somewhat larger number of Croatian refugees from Bosnia and Herzegovina who mostly settled in Sydney.

\section{Croatian, not Yugoslav}

The postwar Croatian migrants, and in particular those that came in the early postwar years, differed from the interwar migrants, not only because they came from all regions of Croatia and Bosnia and Herzegovina. They were very proud of their Croatian nationality and cultural heritage, and the great majority supported the idea of an independent and democratic Croatia, and refused to be referred to as Yugoslavs. A prominent left wing, Yugoslav-oriented Croat, an interwar migrant in Sydney, wrote that the political orientation of the Federation of Yugoslav Immigrants in Australia encountered serious difficulties with the arrival of the displaced persons as

many, in contrast to resident Yugoslav Australians, placed great importance on ethnic exclusiveness and cultural separatism ... [Australia saw] the beginning of Croatian, Serbian, Slovenian and other communities at the expense of Yugoslav activities. ${ }^{30}$

Like many other Croatian communities around the world, postwar Croatian migrants in Sydney directed all their political, social, cultural and intellectual efforts to the struggle for Croatian national independence and secession from Yugoslavia. Unlike their interwar predecessors, they took up the challenge to engender a Croatian identity in Sydney. This group set the nationalist direction of the community and founded a plethora of Croatian associations, clubs, sporting and cultural organisations, welfare associations, churches and language schools which affirmed the Croatian identity in an urban environment which encouraged multiculturalism and cultural 
pluralism as social ideals. Their efforts and achievements were immensely boosted by those Croatian migrants who arrived in Australia in the 1960s and 1970s.

The pinnacle of their engagement came with the independence and proclamation of the Croatian Republic in 1991. Their efforts were rewarded with a visit by the first President of the Republic, Dr Franjo Tuđman, in 1995, and later visits by diverse state officials and academics. The Croatian Consulate General opened in Sydney in 1992, in premises purchased by the local Croatian community. During the 1990s quite a few Sydney Croatians departed for home, contributing to the further development of an Australian-Croatian transnational space.

\section{New community associations}

The first new Croatian association was founded in 1951 in Maroubra Junction under the name Australian-Croatian Association (Australsko-hrvatsko društvo). ${ }^{31}$ The association is now named Croatian Association 'Sydney', (Hrvatsko društvo 'Sydney') - it is located in Punchbowl and operates under the business name Croatian Club Ltd. Later, seven more Croatian clubs were established in the Sydney metropolitan area. Besides being important meeting places, the clubs are home to many social, cultural and sporting groups. Their activities help transfer and maintain the rich cultural traditions of Croatian migrants as well as promote Croatian identity in Sydney.

The first Croatian welfare association in Australia, Croatian Caritas, was founded in Sydney in 1952 to help new migrants with language difficulties find jobs, as well as to provide some measure of financial security. A cooperative society of Croatian farmers was founded in 1958 at the instigation of Zvonimir Zoricich. It was situated on 112 hectares of land near Liverpool and it attracted about 40 Croatians. ${ }^{32}$

There are many sporting organisations in the Croatian community in Sydney, but no other sport is as popular as football (soccer). Sydney Croatia Football Club (now Sydney United) was established in 1958 and

has a pedigree second to none in producing players that have played professionally overseas and represented Australia at youth and full international level. ${ }^{33}$

For Croatians in Sydney, as elsewhere, football was more than a sport. Through football clubs named Croatia, they expressed their aspirations for affirmation of the Croatian name as well as their contribution to the Croatian struggle for independence and sovereignty, which was ultimately achieved in the 1990s. ${ }^{34}$ For three decades, Sydney Croatia's fierce competitor, not only in the football competition, was the Yugal social and soccer club, established mostly by proYugoslav Croatian migrants in 1960; this club followed the earlier established football club Dalmatinac. ${ }^{35}$ The club Yugal vanished with the Yugoslav state. 
In the 1960s, the following Croatian associations and clubs were established: King Tomislav Croatian Club, Edensor Park (with a football stadium for 10,000 spectators); Croatian Club Jadran Hajduk, St John's Park (which has its own football stadium and operates a joint football club with Maltese migrants); and Croatian cultural association Bosna which also has football grounds in St Marys. The 1970s and 1980s saw the establishment of the Australian Croatian Cultural and Educational Association Braća Radić in Schofields, Dalmacija Sydney Croatian Club in Terrey Hills with whom the prewar Orjen club later amalgamated, Istra Social and Sports Club in Leppington, and the Association St Maria from the Island of Cres (SMOC) in Marsden Park. ${ }^{36}$ Nearly all of these clubs have several lanes for bocce, or Mediterranean hard court bowling, a favourite pastime of most Croatians from the Adriatic regions.

\section{Religion and culture}

The Croatian Catholic congregation was founded in the 1950s. ${ }^{37}$ Following the leading role of the Catholic Church in Croatian history, the Croatian Catholic priests were involved, from their first days in Australia, in promoting Croatian ethnic identity, language and cultural heritage. ${ }^{38}$ There are three Croatian Catholic Centres in Sydney today, of which two were blessed and opened in 1985 by Cardinal Franjo Kuharić, the Archbishop of Zagreb.

In 1966 Croatians bought two Congregational churches built in 1889 and 1907 in Summer Hill and established their own St Anthony's Croatian Catholic Church. With the generosity of the Croatian faithful in Sydney, this church has been restored and renovated with a spacious new centre which includes offices and living quarters. Father Ivan Mihalić and Father Rok Romac were the first Croatian Catholic priests to serve the Croatian community in Sydney.

In the 1980s Croatians commemorated 13 centuries of Christianity. In the spirit and enthusiasm of these celebrations, Croatian migrants once again dug deep into their pockets, raising more than $\$ 1$ million which has helped build Croatian churches and centres in St John's Park and Blacktown. Both places of worship were officially opened in 1985. Next to the St Nikola's Tavelic church in St John's Park, Cardinal Stepinac Retirement Village, an aged-care hostel, has been built and developed. This is the first Croatian nursing home in Sydney. ${ }^{39}$ In the early 1990 s, a Croatian Seventh-day Adventist church was established in Dundas.

Croatian folk dance, music and song have been a large part of Croatian migrants' lives. The first folkloric groups and ensembles were founded in the early 1960s, but it was not until the Croatian Folkloric Group (Hrvatska folklorna grupa) won first place as best folkloric group at the Waratah Spring Festival, held in Sydney Town Hall in 1967, that folklore became a very important medium of promoting Croatian identity. The name of the group was changed to Koleda Croatian Folkloric Ensemble in 1969 and it subsequently emerged as one of the most thriving and influential Croatian folk dance ensembles in Australia. ${ }^{40}$ 
During the 1970s a number of Croatian folkloric groups sprang into existence in Sydney, each generally associated with one of the social clubs. The Association of Croatian Folkloric Groups was established in 1978 with the aim to coordinate the folkloric groups' activities and promote Croatian dance folklore and culture. These are some of the active folkloric groups in Sydney: Braća Radić, Dalmacija, Jadran, Koleda, Linđo, Mladi Frankopani, and Vukovar. Today, Vukovar, founded in 1984, stands as Australia's premier folkloric group.

\section{New Croatian media}

Since the early 1950s, there has been a diversified Croatian community media in Sydney. The Australian-Croatian Association's bulletin Hrvat (The Croat) was the first publication of the postwar Croatian migrants. The first issue of Spremnost (Readiness) was published in $1957 .{ }^{41}$ Its almost regular weekly publication continued from 1958 until Christmas 2007. In the 1970s, the Free Croatian Radio Program on radio 2SER and the Program in Croatian Language on SBS Radio began broadcasting.

On the left and pro-Yugoslav spectrum, interwar Croatian migrants began a publication Jugoslavensko-Australski list (Yugoslav-Australian paper). In 1970 this paper became Novo Doba (New Age) ${ }^{42}$ and continued its publication until the break-up of Yugoslavia. After that it briefly changed its name to Novo vrijeme (New Time) and in 2008 publishes under the name Nova Hrvatska (New Croatia Weekly). From the 1980s, there have been several community-based radio programs, the most popular being CRO2000 Radio which has linked Croatian Australian youth with local and overseas events since 1992, with Croatian Community Radio Program and Croatian National Radio Program later broadcasting live. Recently, the Croatian community in Sydney began broadcasting a TV program and in February 2008 SBS television programming was expanded with Sunday morning news in Croatian.

\section{Preserving language and culture}

Language has a special role in Croatian culture and in preserving Croatian identity. The first school of Croatian language in Sydney opened on the initiative of Father Rok Oswald Toth and Dr Harasty Draganović in 1963 in Croatian House (Hrvatski dom) in Buckingham Street, Surry Hills. ${ }^{43}$ The number of schools rapidly grew in the Sydney metropolitan area and in 1977 the Central Council of Croatian Schools in New South Wales (Središnji odbor hrvatskih etničkih škola u New South Wales) was founded. In 1983 a Croatian language program was introduced at Macquarie University and in 1984 the Croatian Studies Foundation was established, supported by generous donations from hundreds of individuals and Croatian organisations Australia-wide.

Macquarie University became one of the first tertiary institutions in the world where Croatian language, Croatian literature and culture enjoyed full academic and cultural autonomy, freedom and independence. With its Croatian Studies Centre, Macquarie University still offers a program 
in Croatian Studies. ${ }^{44}$ Macquarie University has agreements on international cooperation with the Croatian universities of Zagreb, Split and Zadar, allowing Sydney students to study in Croatia as part of their degrees.

Luka Budak is Director of the Croatian Studies Centre, Division of Humanities, Macquarie University, Sydney

Walter F Lalich is Research Associate in the Croatian Studies Centre, Division of Humanities, Macquarie University, Sydney

\section{Acknowledgments}

We would like to thank very much Tom Gergich, Marin Grubisich, Steven Kosovich, and the late Andrija Segedin for their valuable support and information that greatly enhanced the quality of the presentation of the earlier period of Croatian settlement in Sydney.

\section{Endnotes}

${ }^{1}$ Charles A Price, Southern Europeans in Australia, Oxford University Press, Melbourne, 1963, pp 11, 23; Steven Kosovich, 'Yugoslavs', in James Jupp (ed), The Australian People, Cambridge University Press, Melbourne, 2001, p 747

${ }^{2}$ Peter Spearritt, Sydney Since the Twenties, Hale \& Iremonger, Sydney, 1978, p 93

${ }^{3}$ Australian Bureau of Statistics, 2006 Census of Population and Housing, cat no 2068.0-Census Tables

${ }^{4}$ Mato Tkalcevic, Croats in Australia, Victoria College Press, Melbourne, 1988, p 7; Mary Stenning, Croatian and Slav Pioneers, New South Wales 1800s-1940s, Fast Books, Sydney, 1996, pp 4, 27; Mary Stenning, Croatian and Slav Pioneers of Australia, Fast Books, Sydney, 1999, pp 26, 94

${ }^{5}$ Mary Stenning, Croatian and Slav Pioneers, New South Wales 1800s-1940s, Fast Books, Sydney, 1996, p 53

${ }^{6}$ Mary Stenning, Austrian Slavs: Internment Camps of Australia World War I, Fast Books, Sydney, 1995; Anthony Splivalo, The Home Fires, Fremantle Arts Centre Press, Fremantle, 1982; Gerhard Fischer, Enemy Aliens: Internment and the Homefront Experience in Australia 1914-1920, Queensland University Press, Brisbane, 1989; National Archives of Australia, Sydney, Register of World War I Internees in New South Wales, 1914-1918, C440

${ }^{7}$ Charles A Price, Southern Europeans in Australia, Oxford University Press, Melbourne, 1963, pp 143, 182; Mary Stenning, Croatian and Slav Pioneers of Australia, Fast Books, Sydney, 1999, pp 53, 68; Marin Alagich and Steven Kosovich, 'Croatians', in James Jupp (ed), The Australian People, Cambridge University Press, Melbourne, 2001, p 237; Tom Gergich, personal information, 2007

${ }^{8}$ Luka Markovic, Pod Australskim Suncem (Under the Australian Sun), JAZU, Zagreb, 1973, p 156

${ }^{9}$ Luka Markovic, Pod Australskim Suncem (Under the Australian Sun), JAZU, Zagreb, 1973, p 209; Mary Stenning, Croatian and Slav Pioneers, New South Wales 1800s-1940s, Fast Books, Sydney, 1996, pp 93111; Bart Srhoy, Journey Beyond Origin, Hesperian Press, Perth, 1998, pp 67-94

${ }^{10}$ Charles A Price, Southern Europeans in Australia, Oxford University Press, Melbourne, 1963, p 241; Luka Markovic, Pod Australskim Suncem (Under the Australian Sun), JAZU, Zagreb, 1973, p 286; Mato Tkalcevic, Croats in Australia, Victoria College Press, Melbourne, 1988, pp 25-6; Marin Alagich and 


\section{Endnotes}

Steven Kosovich, 'Croatians', in James Jupp (ed), The Australian People, Cambridge University Press, Melbourne, 2001, p 238

${ }^{11}$ Tom Gergich, personal information, 2007

${ }^{12}$ Marin Alagich and Steven Kosovich, 'Croatians', in James Jupp (ed), The Australian People, Cambridge University Press, Melbourne, 2001, p 239

${ }^{13}$ Tom Gergich, personal information, 2007; Steven Kosovich, personal information, 2008

${ }^{14}$ Mato Tkalcevic, Croats in Australia, Victoria College Press, Melbourne, 1988, p 52-53; Steven Kosovich, personal information, 2008

${ }^{15}$ Mary Stenning, Croatian and Slav Pioneers, New South Wales 1800s-1940s, Fast Books, Sydney, 1996, p 82; Tom Gergich, personal information, 2007

${ }^{16}$ Mato Tkalcevic, Croats in Australia, Victoria College Press, Melbourne, 1988, p 52

${ }^{17}$ Mato Tkalcevic, Croats in Australia, Victoria College Press, Melbourne, 1988, p 53; Napredak, 24 May 1947, p 11; Tom Gergich, personal information, 2007

${ }^{18}$ Branka Bezić-Filipović, 'Hajduk' i Iseljenici ('Hajduk' and Emigrants), Matica Iseljenika, Split, 2007

${ }^{19}$ Marin Alagich and Steven Kosovich, 'Croatians', in James Jupp (ed), The Australian People, Cambridge University Press, Melbourne, 2001, p 238; Mary Stenning, Croatian and Slav Pioneers, New South Wales 1800s-1940s, Fast Books, Sydney, 1996, p 119

${ }^{20}$ Mato Tkalcevic, Croats in Australia, Victoria College Press, Melbourne, 1988, pp 28, 73; Miriam Gilson and Jerzy Zubrzycki, The Foreign Language Press in Australia 1848-1964, Australian National University Press, Canberra, 1967, pp 148-149

21 '246 Sail in Ship for Yugoslavia', Sydney Morning Herald, 20 January 1948, p 3; '500 Yugoslavs Leaving Australia', Daily Telegraph, 9 January 1948, p 7; 'Clenched Fists as Ship Sails: 4000 Farewell Yugoslavs', Daily Telegraph, 20 January 1948, p 9; 'Calwell's Warning to Slavs', Daily Mirror, 20 January 1948, p 3; National Archives of Australia, Sydney, Passenger List-Outgoing Passengers, SP $1148 / 2$

${ }^{22}$ Charles A Price, Southern Europeans in Australia, Oxford University Press, Melbourne, 1963, pp 207216, 284, 294; Anthony Splivalo, The Home Fires, Fremantle Arts Centre Press, Fremantle, 1982, p 225; Anastasios Tamis, The Immigration and Settlement of Macedonian Greeks in Australia, La Trobe University Press, Melbourne, 1994, pp 108-113; Bart Srhoy, Journey Beyond Origin, Hesperian Press, Perth, 1998, pp 63-67, 91

${ }^{23}$ Marin Grubisich, personal information, 2007

${ }^{24}$ Luka Budak, 'Postwar Croatian Settlement', in James Jupp (ed), Australian People, Angus \& Robertson, Sydney, 1988, p 342

${ }^{25}$ Gracian Biršić, 'Croatian Settlement Since 1960', in James Jupp (ed), Australian People, Angus \& Robertson, Sydney, 1988, p 337; Val Čolić-Peisker, 'Australian Croatians at the Beginning of the Twenty-First Century: A Changing Profile of the Community and its Public Representation', Croatian Studies Review, Sydney, 2004-2005, vol 3-4, p 6

${ }^{26}$ Gracian Biršić, 'Croatian Settlement Since 1960', in James Jupp (ed), Australian People, Angus \& Robertson, Sydney, 1988, p 343 


\section{Endnotes}

${ }^{27}$ Val Čolić-Peisker, 'Australian Croatians at the Beginning of the Twenty-First Century: A Changing Profile of the Community and its Public Representation', Croatian Studies Review, Sydney, 2004-2005, vol 3-4, p 7

${ }^{28}$ Gracian Biršić, 'Croatian Settlement Since 1960', in James Jupp (ed), Australian People, Angus \& Robertson, Sydney, 1988, p 343; Val Čolić-Peisker, 'Australian Croatians at the Beginning of the Twenty-First Century: A Changing Profile of the Community and its Public Representation', Croatian Studies Review, Sydney, 2004-2005, vol 3-4, p 6; Vesna Drapač, 'Perceptions of Post-World War Croatian Immigrants: The South Australian Case', Croatian Studies Review, Sydney, 2004-2005, vol 34, pp 29-31

${ }^{29}$ Val Čolić-Peisker, 'Australian Croatians at the Beginning of the Twenty-First Century: A Changing Profile of the Community and its Public Representation', Croatian Studies Review, Sydney, 20042005, vol 3-4, p 9

${ }^{30}$ Marin Alagich, 'Early Croatian Settlement in Eastern Australia', in James Jupp (ed), Australian People, Angus \& Robertson, Sydney, 1988, p 337

${ }^{31}$ Mato Tkalčević, Hrvati u Australiji (Croatians in Australia), Nakladni Zavod Matice Hrvatske, Zagreb, 1992, pp 138-139

${ }^{32}$ Luka Budak, 'Postwar Croatian Settlement', in James Jupp (ed), Australian People, Angus \& Robertson, Sydney, 1988, p 342

${ }^{33}$ Sydney United Football Club, official website, http://www.sydneyunited.com.au/index.html,, viewed 2 December 2008

${ }^{34}$ Marin Sopta, 'Stotine iseljeničkih športskih klubova s imenom Croatia' (Hundreds of Sports Clubs in the Emigrant Communities Bear the Name Croatia), in Hrvatski iseljenički zbornik, Zagreb, 2008, pp 419426

${ }^{35}$ Marin Alagich and Steven Kosovich, 'Croatians', in James Jupp (ed), The Australian People, Cambridge University Press, Melbourne, 2001, p 239

${ }^{36}$ Walter Lalich, 'The Development of Croatian Communal Places in Sydney', in Croatian Studies Review, Sydney, 2004-2005, vol 3-4, pp 111-113

${ }^{37}$ Mato Tkalčević, 'Religion and Ethnic Identification Amongst Croatian Australians', in Religion and Ethnic Identity, An Australian Study, in Abe Wade Ata (ed), Spectrum Melbourne, 1984, vol III, p 63

${ }^{38}$ Walter Lalich, 'The Development of Croatian Communal Places in Sydney', in Croatian Studies Review, Sydney, 2004-2005, vol 3-4, p 112

${ }^{39}$ Teresa Crvenković, 'Dancing in Koleda's Circle: A Performative Analysis of Croat Folk Dance in Australia', MPhil thesis, University of Sydney, 2005, pp 3-6

${ }^{40}$ Luka Markovic, Pod Australskim Suncem (Under the Australian Sun), JAZU, Zagreb, 1973, p 154; Mato Tkalcevic, Croats in Australia, Victoria College Press, Melbourne, 1988, pp 72-73; Miriam Gilson and Jerzy Zubrzycki, The Foreign Language Press in Australia 1848-1964, Australian National University Press, Canberra, 1967, pp 23, 147

${ }^{41}$ Mato Tkalčević, Hrvati u Australiji (Croatians in Australia), Nakladni Zavod Matice Hrvatske, Zagreb, 1992, p 139

${ }^{42}$ Marin Alagich and Steven Kosovich, 'Croatians', in James Jupp (ed), The Australian People, Cambridge University Press, Melbourne, 2001, p 748 


\section{Endnotes}

${ }^{43}$ Mato Tkalčević, Hrvati u Australiji (Croatians in Australia), Nakladni Zavod Matice Hrvatske, Zagreb, 1992, p 158

${ }^{44}$ Luka Budak, 'Dva desetljeća Hrvatskog studija na Sveučilištu Macquarie u Sydneyu' (Two Decades of Croatian Studies at Macquarie University in Sydney), in Croatian Studies Review, Sydney, 2002-2003, vol 2, pp 368-377 